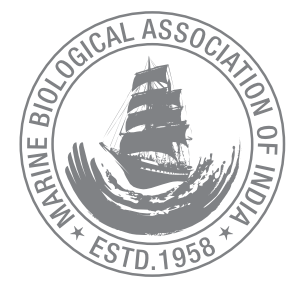

\title{
Effect of Acetic acid treatment on the control of non-indigenous ascidians in farmed Indian pearl oyster Pinctada fucata
}

\author{
S. Chinnadurai*, I. Jagadis ${ }^{1}$, V. K. Meenakshi ${ }^{2}$ and K. S. Mohamed ${ }^{3}$ \\ ICAR-Central Institute of Fisheries Technology, Kochi-682029, Kerala, India. \\ ${ }^{1}$ Tuticorin Research Centre of ICAR-Central Marine Fisheries Research Insitute, Tuticorin, Tamil Nadu, India. \\ ${ }^{2}$ A.P.C. Mahalaxmi College for Women, Tuticorin, Tamil Nadu, India. \\ ${ }^{3}$ ICAR-Central Marine Fisheries Research Institute, Kochi-682018, Kerala, India. \\ *Correspondence e-mail: chinnaduraitvl@gmail.com
}

Received: 10 Oct 2018 Accepted: 25 Jan 2019 Published: 30 Jan 2019

Original Article

\begin{abstract}
Control of biofouling has been one of the major challenges in pearl culture. Field experiments were performed to control the biofouling in farmed pearl oyster Pinctada fucata by treating the oysters first with $5 \%$ acetic acid at different time interval $(2,5,10 \mathrm{~min})$ and then kept for evaluation at three depths $(1,3,5 \mathrm{~m})$. The average total fouling biomass on oysters exposed for 2, 5, 10 min were 7.35, 6.97 and $6.49 \mathrm{~g} /$ oyster/month respectively, while control showed 10.56 $\mathrm{g} /$ oyster/month on completion of four months. Mortality of oysters were $60,29,14 \%$ at 10,5 and 2 min exposure and control had only $7 \%$. There was significant differences in total fouling biomass and mortality between the control and treatments $(p<0.001)$. Results suggest that 2 min exposure of oysters in acetic acid and deployed at a depth of $3 \mathrm{~m}$ was found to be best for reducing biofouling as well as more effective in preventing the settlement of non-indigenous ascidians, especially Didemnum sp. The outcome of the present study may contribute to further optimise the current antifouling managements in pearl culture and fill the knowledge gap for farming practices and their management specifically with reference to the monitoring and cleaning procedures.
\end{abstract}

Keywords: Biofouling, Indian Pearl oyster, acetic acid treatment, depth, mortality

\section{Introduction}

India had a long and rich history in natural pearl fisheries until early 1960 's. During the period 1966-67 there was no fishery at all, due to depleted oyster population (Alagarswami and Qasim, 1973). Pearl culture programme was initiated by the Tuticorin Research Centre of ICAR-Central Marine Fisheries Research Institute, in Gulf of Mannar during early 1970's and subsequently success was reached in 1973 (Alagarswami, 1974). The dissemination of pearl culture in India by different schemes started in the year 1976 and is still continuing. Though attempts were made by CMFRI for commercialization of marine pearl culture with fisher folks and entrepreneurs, the anticipated commercialization of pearl culture has not been accomplished so far because of various problems (Jagadis et al., 2015). One of the major concern in shellfish farming is control of biofouling (Velayudhan, 1983; Dharmaraj et al., 1987), especially the non-indigenous ascidians which significantly affect the industry (LeBlanc et al., 2007; Switzer et al., 2011). Biofouling of aquaculture facilities by non-indigenous ascidians is a major problem, especially with the culture of oysters and scallops, which are grown in net cages (Bullard et al., 2013). These fouling organisms on aquaculture nets, reduces the growth of the cultured species because the fouling species compete with the target species for food and reduce water flow through the nets (Lesser et al., 1992; Lutz-Collins et al., 2009). The frequent 
scraping of the fouling species off nets greatly increases the cost of aquaculture (Hodson et al., 1997).

Biofouling which refers to the accumulation of microorganisms, plants, algae or other animals on suspended cultivation of pearl oyster is a serious problem worldwide. The three major concerns for loss in pearl oyster cultures are foulers, borers and predators. The settlement and growth of fouling organisms keep the available food under competition, while the borers damage the animal shells making it weak and fragile. The predators also directly feed on the organisms (Doroudi, 1996). The loss in the form of mortality due to these causes may also be through disease causing and physiological stress development in growing oysters. Hence it is essential to remove/protect the pearl oysters from foulers, borers and predators. This is a labor intensive activity under current farming practices (de Nys and Ison, 2004). According to Taylor et al. (1997) and Kripa et al. (2012), the recommended time interval for cleaning of farmed pearl oyster in tropical condition is 30 days. It has been estimated that 25$30 \%$ of operational cost goes for the prevention and removal of fouling on both pearl oyster and culture equipment (de Nys and Ison, 2008). Moreover, the frequent manual handling and aerial exposure may cause some degree of stress on the oysters (Taylor et al., 1997; Lacoste et al., 2014). On the whole, pearl culture is affected detrimentally by biofouling process. Hence, the control of biofouling is imperative to ensure the quality of pearl and growth of the pearl culture industry.

Considerable research has been done on biofouling of farmed pearl oyster in India (Alagarswami and Chellam, 1976; Velayudhan, 1983, 1987; Dharmaraj et al., 1987; Kripa et al., 2012). There are no studies on the control strategies of fouling organisms. Despite several studies highlighting the significance of acetic acid treatment to reduce biofouling in oyster culture (Guenther et al., 2006; Leblanc et al., 2007; Forrest et al., 2007; Rolheiser et al., 2012), its efficacy in the long run is lacking. To overcome these problems, experiments were undertaken to improve knowledge on the temporal variations in the occurrence of dominant foulers and predators of pearl oysters, and to develop suitable techniques such as different exposure time to acetic acid and influence of depth for control of biofouling in farmed Indian pearl oyster Pinctada fucata.

\section{Material and methods}

\section{Study area/period}

The study was conducted at ICAR-CMFRI, Pearl culture farm, New Harbour, Tuticorin $\left(8^{\circ} 45^{\prime} 03.18^{\prime \prime}\right.$ N 78 $12^{\prime} 16.31^{\prime \prime}$ E, Fig.1)

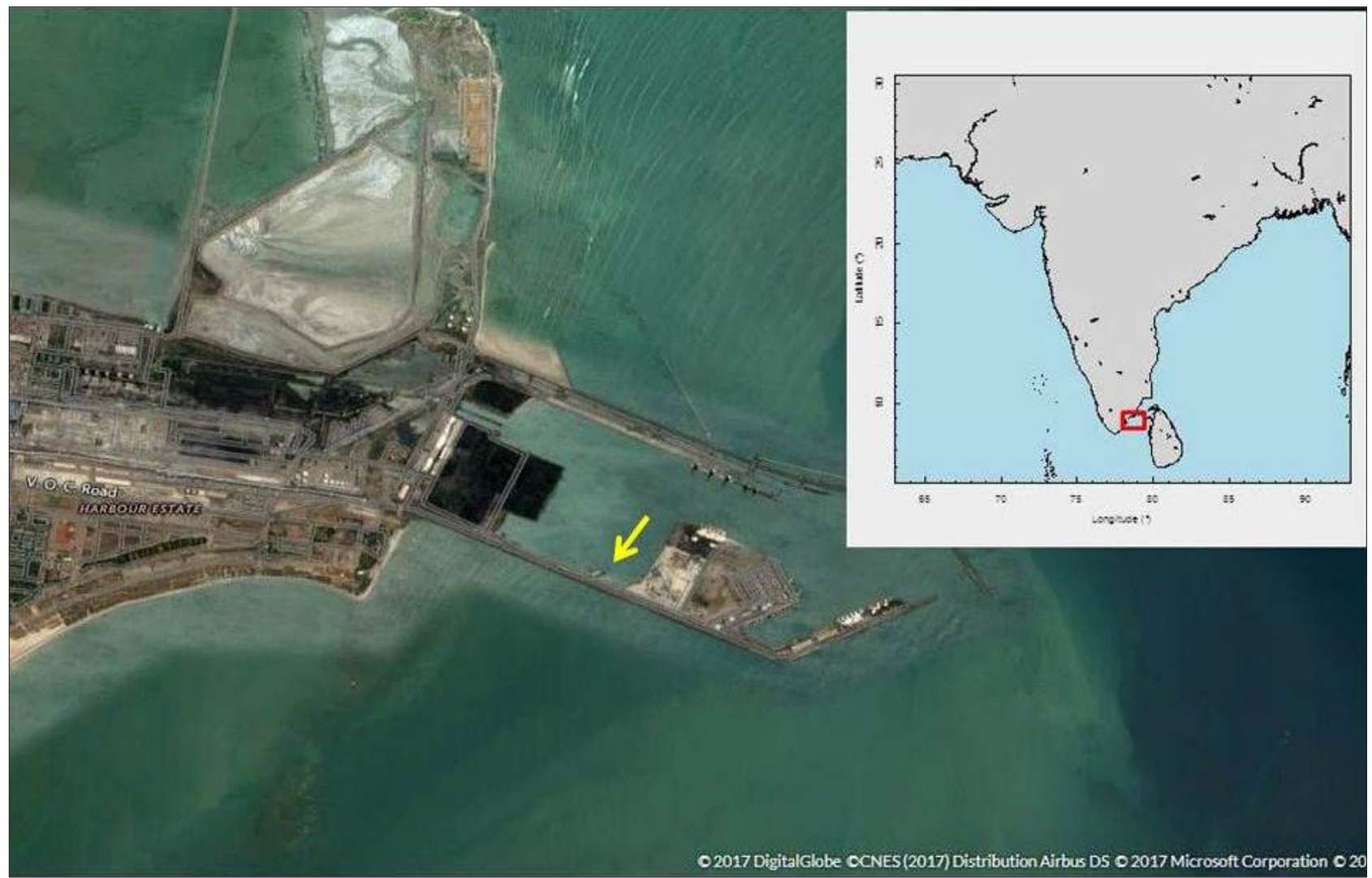

Fig. 1. Map showing the Study Area of Wadge Bank, South India. 
which is a breakwater made for barge jetty. As per literature survey the study period was selected from $16^{\text {th }}$ July to $12^{\text {th }}$ November 2015, due to the intensity of fouling organisms. This place was chosen because of the limited wave action. The maximum depth of the site was $6 \mathrm{~m}$. All the cages $(40 \times 40 \times 12$ $\mathrm{cm})$ were suspended from a wooden raft $(5 \times 5 \mathrm{~m})$ which was moored using anchors.

\section{Fouling control treatments and experimental set-up}

Before starting the experiments, fouling organisms were removed from all oysters by gentle cleaning with a knife and then brushed with seawater. To minimize variation same cohort oysters (2 years old) were selected for the study. The average length, width, height and total weight of oyster was $67.57 \pm 5.56$ $\mathrm{mm}, 63.69 \pm 5.82 \mathrm{~mm}, 29.03 \pm 3.27 \mathrm{~mm}$, and $68.48 \pm 8.24$ $\mathrm{g}$, respectively. A total of 300 adult pearl oysters were used (i.e. 12 batches $\times 25$ oysters $=300$ experimental oysters). Initial stocking density was maintained uniformly at 25 oysters per cage. Mortality in the treated oysters, it went on reducing the stocking density per cage. They were immersed in 5\% acetic acid solution at three different time exposures $2 \mathrm{~min}(\mathrm{~T}-\mathrm{I}), 5$ $\min (\mathrm{T}-\mathrm{II})$, and $10 \mathrm{~min}$ (T-III), respectively. Dip in $5 \%$ acetic acid proved to be effective in reducing biofouling in blue mussel, Mytilus edulis (LeBlanc et al., 2007). The control oysters were not treated with acetic acid. The cages were suspended at three different depths (1, $3 \& 5 \mathrm{~m})$. The oysters were observed on $10^{\text {th }}, 16^{\text {th }}, 22^{\text {td }}, 30^{\text {th }}, 47^{\text {th }}, 60^{\text {th }}$ and $120^{\text {th }}$ day for fouling diversity, total biomass and mortality of oysters.

\section{Assessment of fouling diversity, biomass and oyster survival}

Effect of various acetic acid exposure time and subsequently to different depths were monitored by assessing fouling, biomass and survival for 4 months. Weight of individual oysters were measured at every sampling, including the fouling organisms which settled on both sides of the oyster shells. They were photographed and the images were used to identify the fouling organisms (excluding algae) to the lowest taxonomic level possible (Rolheiser et al., 2012). The biomass of the fouling community was calculated by difference between the initial weight (cleaned oyster) and final weight (with fouling) of oysters. Chellam $(1978 ; 1988)$ recorded the growth increment and other shell attributes of $P$. fucata for farm grown oysters and found that the smaller sized groups exhibited continuous growth and the bigger sized group (50-60 mm), such as the ones used in the present study, showed negligible growth. Hence, in the present study, it was considered that, increase of oyster weight is due to weight of fouling biomass. The total fouling biomass was divided by number of oysters to represent the fouling on a per oyster basis. Subsequently, it was divided by 30 days to represent the value on a monthly basis. Survival of oysters was calculated by counting number of live oysters in each cage and the dead oysters were removed and not replaced.

\section{Statistical analysis}

Data on survival and biofouling biomass without transformation were analyzed for comparing the effect of depth and time of treatment using two-way ANOVA (SAS v.9.2). In case of significant differences, results were subject to a post-hoc test (Duncan Multiple Range Test).

\section{Results}

\section{Diversity of fouling organisms in farmed pearl oyster}

The fouling assemblages on the experimental pearl oysters comprised of 42 species belonging to 24 Families, 13 Classes, and 10 Phylum. The fouling organisms of the Phyla Chordata (class Ascidiacea), Arthropoda (classes Maxillopoda, Malacostraca), Annelida (class Polychaeta), Cnidaria (class Hydrozoa), Bryozoa (class Gymnolaemata), Mollusca (class Bivalvia), Platyhelminthes (class Turbellaria), Porifera (classes Calcarea, Demospongiae), Nematoda (class Enoplia), and Echinodermata (class Crinoidea) were identified (Table 1). Ascidians were the most prolific fouler found throughout the sampling period followed by bryozoan colonies identified as Bugula neritina. Calcareous worms and barnacles were the next major group identified during the study. The spat of pearl oyster, edible oyster, and the weaving mussel, Modiolus modiolus were also found in limited numbers. Besides, other associated non-fouling fauna like polyclad worm, amphipods, isopods, crabs, and fish juveniles were encountered along with oysters. Over the time, nature of settlement and changes in dominance in fouling species was found to be varied.

\section{Settlement pattern of fouling organisms in farmed pearl oyster}

There was no settlement on treated oysters up to $16^{\text {th }}$ day. But in the control oysters the bryozoans (Bugula neritina) started accumulating from $10^{\text {th }}$ day onwards. The bryozoans were most susceptible to acetic acid treatment. They started settling on the oysters after 22 days in the two and five minute exposed oysters. After $30^{\text {th }}$ day, all oysters were fouled predominantly with bryozoans. The fouling biomass was significantly $(p<0.01$; Table.2) less in the treated oysters. On the $47^{\text {th }}$ day, serpulids 
Table 1. List of fouling and boring organisms settled on the Indian pearl oyster Pinctada fucata shells at experimental site.

\begin{tabular}{l} 
Phylum Chordata \\
\hline Class Ascidiacea \\
\hline Family Ascididae \\
\hline 1. Ascidia sp. \\
\hline 2. Ascidia sydneiensis \\
\hline 3. Phallusia arabica \\
\hline 4. Phallusia nigra \\
\hline Family Corellidae \\
\hline Rhodosoma turcicum \\
\hline Family Didemnidae \\
\hline 1. Trididemnum cerebriforme \\
2. Diplosoma liserianum \\
\hline Family Perophoridae \\
\hline 1. Ecteinascidia venui \\
\hline Family Polyclinidae \\
\hline 1. Polyclinum sp. \\
2. Polyclinum madrasensis \\
\hline Fam Pyuridae
\end{tabular}

Family Pyuridae

$\frac{\text { 1. Microcosmus sp. }}{\text { 2. Microcosmus exasperates }}$

\begin{tabular}{|c|}
\hline Family Polycitoridae \\
\hline
\end{tabular}

1. Eudistoma superlatum
Family Styelidae
1. Symplegma oceania

\begin{tabular}{l}
$\frac{1 . \text { Symplegma oceania }}{\text { 2. Styla canopus }}$ \\
\hline 3. Hydroides norvegicus \\
\hline 4. Serpula vermicularis \\
\hline 5. Nereis sp.
\end{tabular}

\begin{tabular}{l}
$\frac{\text { 5. Nereis sp. }}{\text { Phylum Cnidaria }}$ \\
\hline Class Hydrozoa \\
\hline Family Campanulariidae \\
\hline 1. Obelia sp. \\
\hline Phylum Bryozoa
\end{tabular}

\begin{tabular}{l}
\hline Phylum Bryozoa \\
\hline Class Gymnolaemata \\
\hline Family Alcyonidiidae \\
\hline 1. Alcyonidium sp. \\
\hline Family Membraniporidae \\
\hline 1. Membranipora sp. \\
\hline Family Bugulidae \\
\hline Bugula neritina \\
\hline Phylum Mollusca \\
\hline Class Bivalvia \\
\hline Family Mytilidae \\
\hline 1. Modiolus sp. \\
\hline Family Ostreidae \\
\hline
\end{tabular}

\begin{tabular}{|c|c|c|c|c|c|}
\hline \multirow{2}{*}{$\begin{array}{l}\text { Class Actinopteri } \\
\text { Family Blenniidae }\end{array}$} & \multirow{2}{*}{ Source of variation } & \multicolumn{4}{|c|}{ Accumulation of fouling biomass } \\
\hline & & d.f. & MS & F-ratio & $P$ \\
\hline 1. Blennius steindachneri & Time & 3 & 546.4 & 257.01 & $<0.0001$ \\
\hline Phylum Arthropoda & Treatment & 3 & 216.8 & 101.9 & $<0.0001$ \\
\hline Class Maxillopoda & Depth & 2 & 9.32 & 4.39 & 0.0303 \\
\hline Family Balanidae & Time*Treatment & 9 & 71.22 & 35.83 & $<0.0001$ \\
\hline 1. Amphibalanus amphitrite & Depth* Treatment & 9 & 1.56 & 0.74 & 0.626 \\
\hline Class Malacostraca & Error & 16 & 34.01 & 2.12 & \\
\hline
\end{tabular}

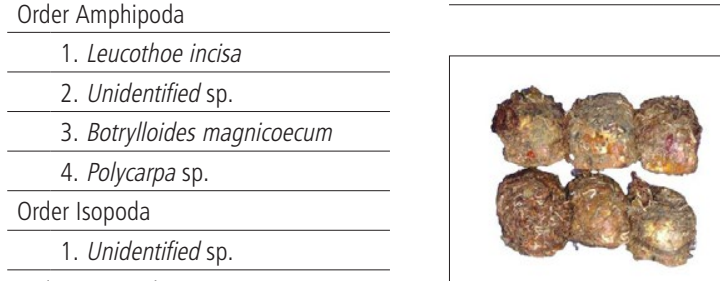

1. Unidentified sp.

Family Pinnotheridae

\section{Pinnotheres sp.}

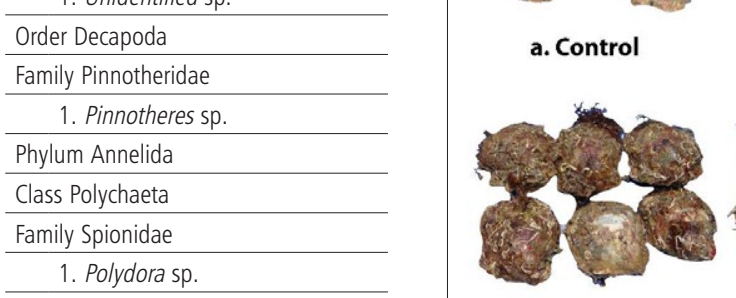

Family Serpulidae

\section{Ficopomatus enigmatica}

2. Hydroides elengans

Family Pteriidae

1. Pinctada fucata

Phylum Platyhelminthes

Class Turbellaria

Family Stylochidae

\section{Stylochus sp.}

Phylum Porifera

\begin{tabular}{l}
\hline Class Calcarea \\
\hline Family Leucosoleniidae
\end{tabular}

1. Leucosolenia sp.

Class Demospongiae

Family Spongiidae

1. Spongia officinalis

Phylum Nematoda

Class Enoplia

Family Enoplidae

\section{Enoplus sp.}

Phylum Echinodermata

Class Crinoidea

1. Unidentified Acid at $3 \mathrm{~m}$ depth. a. 2 Mins Exposure
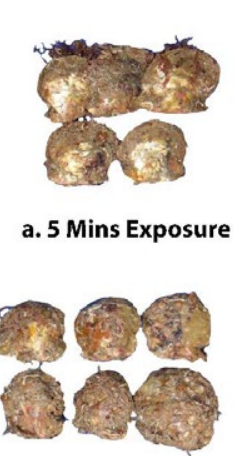

a. 10 Mins Exposure

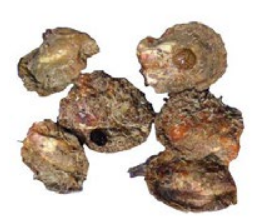

b. Control

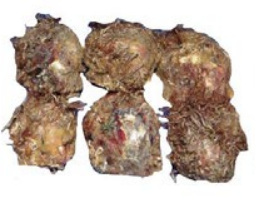

b. 2 Mins Exposure

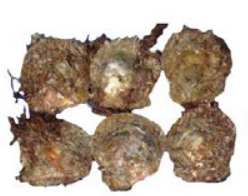

b. 5 Mins Exposure

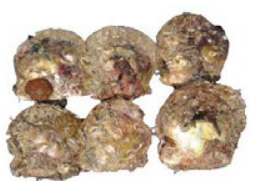

b. 10 Mins Exposure

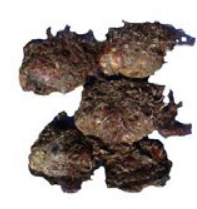

c. Control

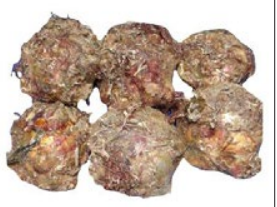

c. 2 Mins Exposure

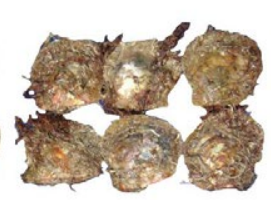

c. 5 Mins Exposure

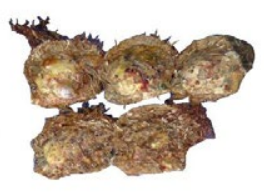

c. 10 Mins Exposure
Fig. 2. Images of fouling development on control and treated oysters (a. 16 th day, b. 30th day c. 47 th day) after 2 minute exposure to $5 \%$ Acetic

\section{Diversity of ascidians in farmed pearl oyster}

During the experimental period of 120 days, fifteen species of ascidians were identified, belonging to eight familiesAscidiidae (3 species), Corellidae (1), Didemnidae (2), Perophoridae (1), Polycitoridae (1), Polyclinidae (1), Pyuridae (2), and Styelidae (4) (Table 1). Though ascidians were present throughout the study period, large ones were dominant in the month of August-September. The highest number of ascidians were recorded at a depth of $5 \mathrm{~m}$ (13 species), followed by $1 \mathrm{~m}$ (12 species), and $3 \mathrm{~m}$ (11 species) respectively. 


\section{Fouling biomass on oysters: effect of exposure to acetic acid and depth}

The impact of acetic acid treatment was clearly evident from the control cages. The exposure of pearl oyster $P$. fucata in acetic acid for different time intervals had significant $(p<0.01$; Table 2) effect on accumulation of total fouling biomass. Of the twelve treatments $(0,2,5,10 \mathrm{~min} \times 1,3,5 \mathrm{~m}$ depth), 10 -minute exposure in acetic acid deployed at $3 \mathrm{~m}$ depth was considerably more effective in controlling fouling organisms (Fig. 3). The mean total fouling biomass on $10 \mathrm{~min}$ (T-III) exposed $P$. fucata shells increased from 1.28 $\pm 0.39 \mathrm{~g} / 0 y$ ster (Mean \pm SD) to $20.09 \pm 5.87 \mathrm{~g} /$ oyster, whereas $5 \mathrm{~min}(\mathrm{~T}-\mathrm{II})$ exposed increased from $1.68 \pm 0.39 \mathrm{~g} /$ oyster to $22.67 \pm 5.22 \mathrm{~g} / \mathrm{oyster}, 2$-min (T-I) exposed increased from $1.99 \pm 0.44 \mathrm{~g} /$ oyster to $24.59 \pm 4.81 \mathrm{~g} /$ oyster and in control it increased from $2.97 \pm 0.71 \mathrm{~g} /$ oyster to $41.84 \pm 0.43 \mathrm{~g} /$ oyster from $16^{\text {th }}$ to $120^{\text {th }}$ day of culture respectively. ANOVA showed significant differences in the outcome of different treatment when compared to the control ( $p<0.001$; Table.2).

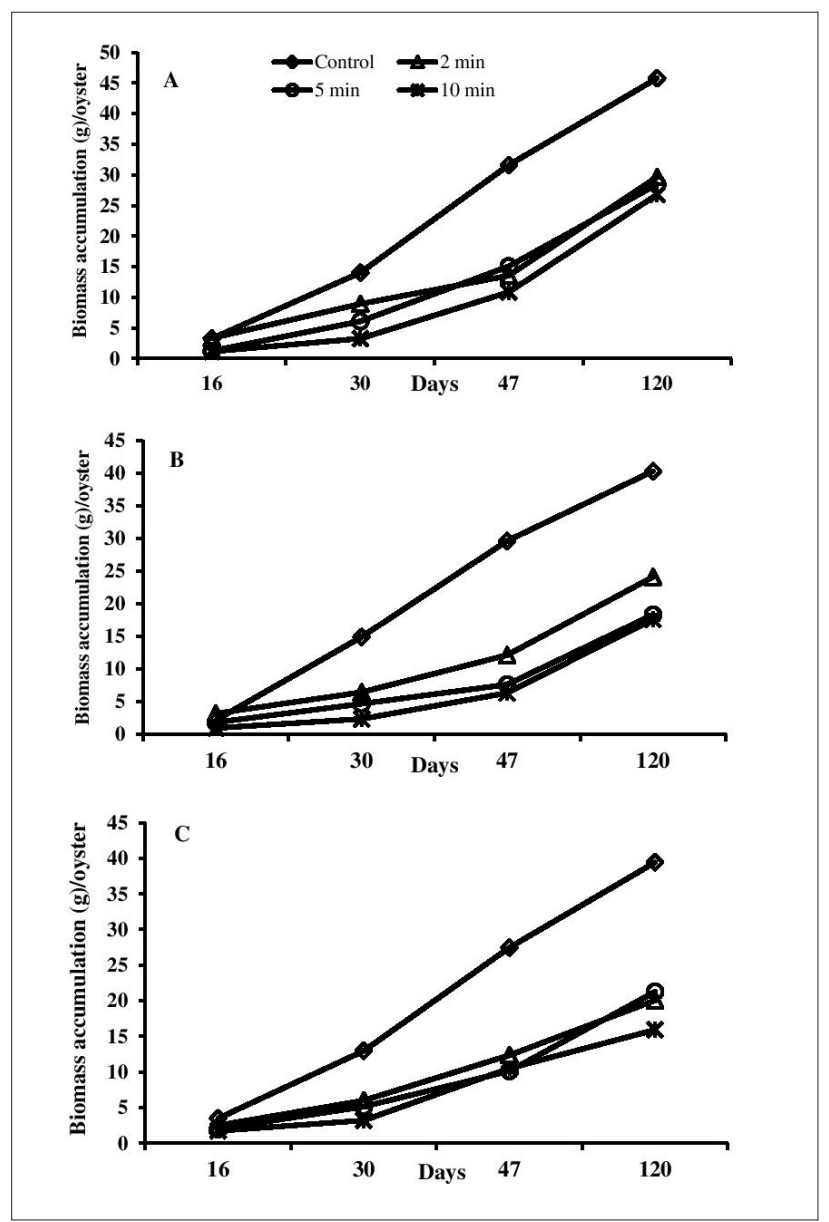

Fig. 3. Effect of acetic acid treatments (5\% acetic acid and 2, 5 \& 10 min exposure) and a control (no treatment) on biomass accumulation of fouling organisms on the shells of farmed pearl oyster ( $P$. fucata) $(\mathrm{g} /$ oyster) A) $1 \mathrm{~m}$ depth, B) $3 \mathrm{~m}$ depth and C) $5 \mathrm{~m}$ depth over 120 days
Ten-minute exposure in acetic acid completely prevented oysters from macro foulers like ascidians and barnacles up to 30 day's post-treatment. Two and five-minute exposure in acetic acid produced shorter period of protection from macro foulers, however, bryozoans and ascidians started fouling on oysters from third week (16 days) of post-treatment. There were also significant $(p<0.001)$ variation in the outcome for different depth of oysters deployed (Table. 2). The average accumulation of fouling biomass on pearl oyster P. fucata deployed in $1 \mathrm{~m}$ depth increased from $2.25 \pm 1.21$ $\mathrm{g} /$ oyster to $32.67 \pm 8.81 \mathrm{~g} /$ oyster, whereas in $3 \mathrm{~m}$ depth it increased from $2.02 \pm 0.90 \mathrm{~g} /$ oyster to $25.06 \pm 10.56 \mathrm{~g} /$ oyster, and in $5 \mathrm{~m}$ depth it increased from $2.42 \pm 0.77 \mathrm{~g} /$ oyster to $24.16 \pm 10.44 \mathrm{~g} /$ oyster from $16^{\text {th }}$ to $120^{\text {th }}$ day of post-treatment respectively.

\section{Pearl oyster mortality: effect of exposure to acetic acid and depth}

The survival of pearl oysters was noted during each sampling by counting the live oysters in each cage separately from which the percentage of mortality was calculated. The oyster mortality rates varied among different treatment and depth deployed. Heavy mortality of oysters was noticed in T-III and $95 \%$ of the mortality occurred within one week of post-treatment. In control cages, very low mortality of $7 \%$ was observed. Of the three different treatment, very high mortality was observed in T-III at 73, 54 and $53 \%$ in 5, 3 and $1 \mathrm{~m}$ depth respectively. Between different treatments, significant $(p<0.01)$ differences in mortality of oyster was recorded (Fig. 4a). On an average in the treatments T-I had $14 \%$ mortality and T-II had $29 \%$ mortality. All oysters treated with acetic acid (T-I, T-II and T-III) and deployed in different depth showed significant decrease $(p<0.01)$ in survival compared to the control oysters (Table 3 ). Among different hanging depths, oysters from $5 \mathrm{~m}$ depth had highest mortality. Between 1 and $3 \mathrm{~m}$ depth no significant differences were obtained (Fig. 4b). The oyster mortality was also significantly $(p<0.01)$ higher when the hanging depth was increased.

Table 3. Analysis of variance (two-way ANOVA) on the effect of depth and treatment on the mortality of farmed pearl oyster $P$. fucata

\begin{tabular}{lllll}
\hline \multirow{2}{*}{ Source of variation } & \multicolumn{4}{c}{ Oyster mortality } \\
\cline { 2 - 5 } & d.f. & MS & F-ratio & $P$ \\
\hline Time & 3 & 5.44 & 2.00 & 0.167 \\
\hline Treatment & 3 & 6125.2 & 2250.1 & $<0.0001$ \\
\hline Depth & 2 & 646.47 & 237.3 & $<0.0001$ \\
\hline Depth* Treatment & 9 & 53.34 & 19.60 & $<0.0001$ \\
\hline Time*Treatment & 9 & 1.81 & 0.67 & 0.677 \\
\hline Error & 16 & 43.55 & 2.72 & \\
\hline
\end{tabular}



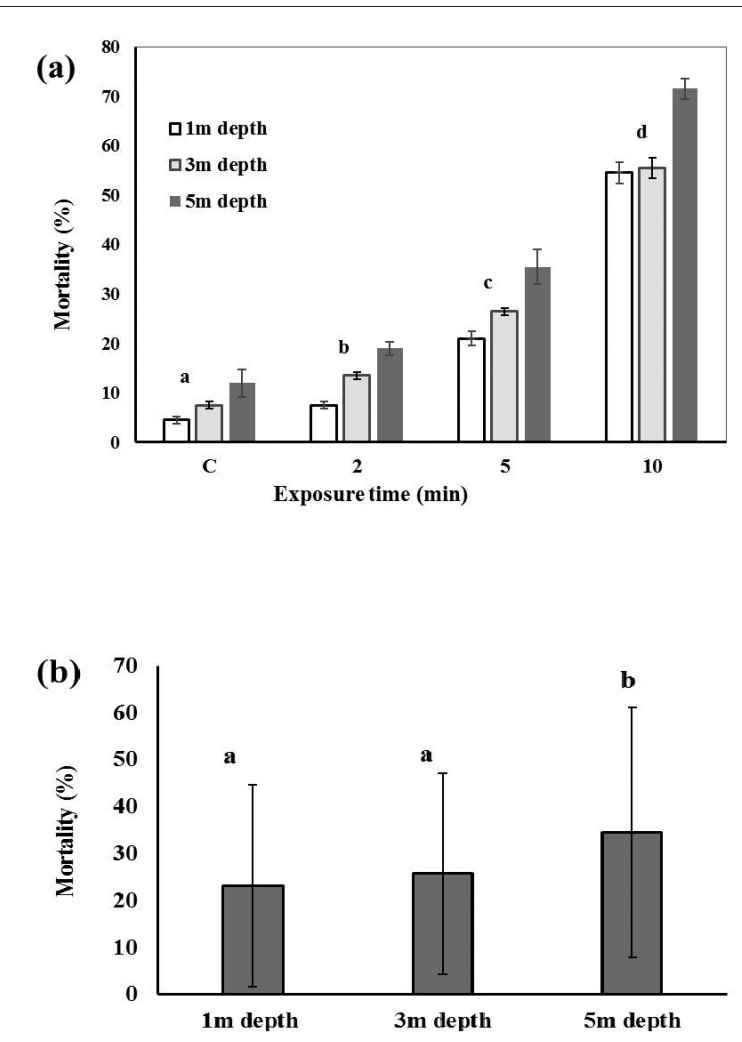

Fig. 4. Effects of acetic acid exposure on mortality rates of pearl oysters (P. fucata) after 120 days: (a) differences between treatments;

(b) differences between depths. Vertical line indicate standard deviation. Non-identical superscripts above the bars indicate significant $(p<0.01)$ differences.

\section{Discussion}

Understanding the diversity of fouling organisms and their recruitment pattern in farmed pearl oysters is crucial in developing a tool to control biofouling. Results of the present study indicated that fouling on pearl oysters can be effectively controlled by acetic acid treatment. Nair (1999), reported that biofouling was a persistent problem throughout the year in Indian coastal waters and its accumulation usually occur quite rapidly. During the study more than 40 fouler species were found to be settled on $P$. fucata shells. Ascidians ( $P$. nigra, A. sydneiensis), bryozoan (B. neritina), serpulid ( $H$. elengans), and barnacle ( $A$. amphitrite) were the dominant communities. The study by Kripa et al. (2012) recorded 25 species of foulers belonging to nine phyla and the dominant fouling community was the ascidian, Didemnum sp. in the pearl farm along southeastern Arabian Sea of India. However, Ali et al. (2015) observed sixteen species of ascidians on the pearl oyster cages from Tuticorin port. In the present study, from the same region, there is a marked increase (from 16 to 18 ) in the number of species of ascidian biofoulers.
In southeastern Arabian Sea, the major fouling ascidian species on $P$. fucata were non-indigenous ascidian of Didemnum sp. (Kripa et al., 2012). Ali et al. (2014) recorded the occurrence of 9 invasive ascidian species on pearl culture cages at Tuticorin port. Meenakshi and Senthamarai (2013) documented 11 species of genus Didemnum at shellfish aquaculture site along Tuticorin coast. Very interestingly, no Didemnum sp. have been observed in treated pearl oysters though it was present in the control oysters in the present study and this may be due to the acetic acid treatment which would have completely inhibited their settlement.

The major issue facing pearl industry is the control of biofouling, in particular non-indigenous ascidians (Switzer et al., 2011; Bullard et al., 2013). To develop a mitigation strategy for invasive ascidians, farmers require more information on ecology, spatialtemporal changes. Recent studies have examined settlement of invasive ascidians in pearl farms in Tuticorin, Gulf of Mannar and found that, 7 out of 16 species were invasive (Ali et al., 2014). The genus Didemnidae is non-indigenous along the east coast of India, but has recently become very abundant and poses a major challenge to pearl culture in the Gulf of Mannar, India (Ali et al., 2014; 2015). This colonial ascidian Didemnum sp. is also of significant concern to aquaculturists in the temperate countries (Bullard et al., 2013; Switzer et al., 2011). To date, however, there have been no studies on the impact of this species on the pearl oysters farmed in Gulf of Mannar, India.

In India the recommended time interval for cleaning the cages and gear is minimum once in a month to mitigate these effects. Farmed pearl oysters are cleaned once in every 4-5 weeks (Taylor et al., 1997; Kripa et al., 2012). Although manual cleaning treatment reduced fouling significantly (Switzer et al., 2011), the operational cost would be very high (Hodson et al., 1997). Reducing the development of fouling community by treating the pearl oysters with chemical has generally shown a positive impact on the pearl oyster culture (Guenther et al., 2006; Leblanc et al., 2007; Forrest et al., 2007; Rolheiser et al., 2012). A number of studies have shown that acetic acid has a significant effect on various species of ascidians and other fouling organisms (Rosa et al., 2013). The acetic acid treatment is generally considered as potential method for controlling the fouling in the oysters (Guenther et al., 2006; Leblanc et al., 2007; Forrest et al., 2007; Rolheiser et al., 2012). This study shows that acetic acid treatment on pearl oyster completely inhibits fouling of non-indigenous ascidian, especially Didemnum sp. Hence it is more beneficial to treat the pearl oysters with acetic acid, rather than to clean them after four weeks.

Collectively, though 5 and 10 min exposure reduced biofouling significantly, our finding suggests that 2 min exposure to acetic acid deployed in $3 \mathrm{~m}$ depth is best for reducing biofouling, with 
high survival rate in field experiment. Two-min exposure to $4 \%$ acetic acid resulted in 100\% mortality of Didemnum vexillum (Mccann et al., 2013). It is suggested that refinement in either exposure time-scale or concentration of acetic acid could significantly decrease fouling biomass in farmed pearl oyster. However, in the present study, acetic acid treatments lowered the survival rates. These findings agree with that of Leblanc et al. (2007) and Rolheiser et al. (2012) and indicate that acetic acid treatment can only be used at low concentrations in pearl farms to control foulers.

Generally, increase in depth and reduction in light intensity, reduce fouling and also cause a significant variation in species diversity and abundance (Cronin et al., 1999). Because biofilm formation of algae decreases with increasing depth (Heath et al., 1992) presence of less diverse fouling community in deeper waters is observed. Overall, fouling biomass has been found to decrease with increasing depth (Moring and Moring, 1975). Similarly, in the present study, a significant difference in settlement of fouling organisms has been observed between depths. Ascidians are the major foulers, where larvae became photonegative and sink into deeper water where the light intensity is low and then swim upward to a darker area for settlement (Kajiwara and Yoshida, 1985). The study on local population ecology of ascidians by Howes et al. (2007) with reference to depth, distribution, and time of recruitment indicated that the local C. intestinalis population explosion is related to availability of predator free recruitment surfaces. The average depth of mussel lines lowered in Nova Scotia is around $4.5 \mathrm{~m}$ depth where more number of $C$. intestinalis have been reported. Furthermore, Aldred and Clare (2014) reported the preference for horizontal surfaces by $\mathrm{H}$. momus, while the preference for floating structures were observed by $P$. nigra and Ascidia cannelata. On the contrary, in the present study no significant difference in settlement of ascidian species were noted between the depths. The highest number of ascidian species was recorded at $5 \mathrm{~m}$ depth (13species).

Monthly change in the fouling community was observed during the study. The fouling community was dominated by bryozoans during August. Subsequently, from September to October ascidians along with the seruplids ( $H$. elengans) were the dominant fouling species in both control and treated oysters. During late October ascidians started disappearing and settlement of barnacles were observed. This may be due to differences in the spawning season of the fouling organisms. Barnacle spawning season is during monsoon in October (Alagarswami and Chellam, 1976). Similarly, in Australia, Taylor et al. (1997) reported heavy settlement of barnacles during rains. On the contrary, Kripa et al. (2012) reported that the dominant foulers in June (monsoon) were
Annelids, during August to September, spat of bivalves, and October to December it was bryozoans and in January, ascidians. This highlights the regional differences in the season of various foulers.

The settlement of non-indigenous ascidians (Didemnum sp.) on suspended pearl oyster culture can be effectively controlled by means of acetic acid dip treatment before they are stocked in cages. This study also showed both in terms of the reduction in the total amount of fouling biomass as well as decline in the number of fouling diversity. The immersion period had a strong effect on the biofouling accumulation and oyster mortality. The present study demonstrates that the oysters immersed in acetic acid solution for $2 \mathrm{~min}$ had significant reduction in fouling biomass and better survival. Immersion period and depth had a remarkable influence on the accumulation of biomass, the richness in species diversity and the composition of community. In practice, the completely effective treatments against fouling organisms may result in mortality to a lesser extent in pearl oysters. These result suggest that acetic acid treatment may be more effective in preventing the settlement of non-indigenous ascidian, especially Didemnum sp. on pearl oyster which is well established in this region. The results of this study may further help to identify suitable strategy for controlling the fouling organisms of Indian pearl oyster during culture and streamline monitoring and cleaning operations of farming and management practices.

\section{Acknowledgements}

This study is from the professional attachment training (PAT) of the first author. The authors are thankful to the Indian Council of Agricultural Research, New Delhi for the financial support. The authors thank the Director ICAR-CMFRI for providing necessary facilities and encouragements to carry out this work. Thanks are due to the Director, ICAR-CIFT and Head of the Fishing Technology Division, for guidance and support. Thanks are also due to Scientist In Charge, ICAR-CMFRI, Tuticorin for facilitating the research activity. Many thanks to J. Padmanathan, N. Jesuraj, Sekar V Rayar, Prince and Sivanesh for the excellent technical support

\section{References}

Alagarswami, K. 1974. Development of cultured pearls in India. Curr. Sci., 43:205-207. Alagarswami, K. and A. Chellam. 1976. On fouling and boring organisms and mortality of pearl oysters in the farm at Veppalodai, Gulf of Mannar. Indian J. Fish, 23:1022.

Alagarswami, K. and S. Z. Qasim. 1973. Pearl culture-its potential and implications in india. Indian J. Fish., 20:533-550.

Aldred, N. and A. S. Clare. 2014. Mini-review : Impact and dynamics of surface fouling by solitary and compound ascidians. Biofouling, 30: 259-270.

Ali, A. J. H., V. Sivakumar, M. Tamilselvi, A. S. Akram and M. L. K. Arshan. 2015. On a collection of ascidians from the southern west coast of India with three new 
records from Indian waters. J. Mar. Biol. Assoc. India, 57: 5-12.

Ali, A. J. H., M. Tamilselvi and V. Sivakumar. 2014. Non- indigenous ascidians in V. 0. Chidambaram port, Thoothukudi, India. Indian J. Geo-Mar. Sci,, 43:2147-2157.

Bullard, S. G., C. V. Davis and S. E. Shumway. 2013. Seasonal Patterns of Ascidian Settlement at an Aquaculture Facility in the Damariscotta River. J. Shellfish Res., 32: $255-264$

Chellam, A. 1988. Growth and biometric relationship of pearl oyster Pinctada fucata (Gould). Indian J. Fish., 35:1-6.

Chellam, A. 1978. Growth of pearl oyster Pinctada fucata in the pearl culture farm at veppalodai. Indian J. Fish., 25:77-83.

Cronin, E. R., A. Cheshire, S. M. Clarke and A. J. Melville. 1999. An investigation into the composition, biomass and oxygen budget of the fouling community on a tuna aquaculture farm. Biofouling, 13:279-299.

de Nys, R. and O. Ison. 2008. Chapter 15 - Biofouling, in: Southgate, P.C., Lucas, J.S. (Eds.), The Pearl Oyster. Elsevier B.V., pp. 527-553.

de Nys, R. and O. Ison. 2004. Evaluation of antifouling products developed for the Australian pearl industry. Douglas, QLD, 4811 Australia.

Dharmaraj, S., A. Chellam and T. S. Velayudhan. 1987. Biofouling, boring and predation of pearl oyster, in: Bull. Cent. Mar. Fish. Res. Inst., pp. 17-24.

Doroudi, M. S. 1996. Infestation of pearl oysters by boring and fouling organisms in the northern Persian Gulf. Indian J. Geo-Mar. Sci., 25:168-169.

Forrest, B. M., G. A. Hopkins, T. J. Dodgshun and J. P. A. Gardner. 2007. Efficacy of acetic acid treatments in the management of marine biofouling. Aquaculture, 262:319-332.

Guenther, J., P. C. Southgate and De R. Nys. 2006. The effect of age and shell size on accumulation of fouling organisms on the Akoya pearl oyster Pinctada fucata (Gould). Aquaculture, 253: 366-373.

Heath C. R., B. S. C. Leadbeater and M. E. Callow. 1993. Formation and calcification of biofilms on anti-fouling paints in hard waters. Biofouling, 7: 29-57.

Hodson, S. L., T. E. Lewis and C. M. Burke. 1997. Biofouling of fish-cage netting: efficacy and problems of in situ cleaning. Aquaculture, 152: 77-90

Howes, S., C. M. Herbinger, P. Darnell and B. Vercaemer. 2007. Spatial and temporal patterns of recruitment of the tunicate Ciona intestinalis on a mussel farm in Nova Scotia , Canada. J. Exp. Mar. Bio. Ecol., 342:85-92.

Jagadis, I., A. C. C. Victor, B. Ignatius, D. Kandasami and A. Chellam. 2015. Indian experience of large scale cultured marine pearl production using Pinctada fucata (Gould) from southeast coast of India : A critical review. J. Mar. Biol. Assoc. India, 57: $58-64$.

Kajiwara, S. and M. Yoshida, 1985. Changes in behavior and ocellar structure during the larval life of solitary ascidians. Biol. Bull., 169:565-577.

Kripa, V., K. S. Mohamed and T. S. Velayudhan. 2012. Seasonal Fouling Stress on the Farmed Pearl Oyster, Pinctada fucata, from Southeastern Arabian Sea. J. World Aquac. Soc., 43: 514-525.

Lacoste, E., Y. Gueguen, Le. G. Moullac, M. S. Koua and N. Gaertner-mazouni. 2014. Influence of farmed pearl oysters and associated biofouling communities on nutrient regeneration in lagoons of French Polynesia. Aquac. Environ. Interact., 5:209-219.

Leblanc, N., J. Davidson, R. Tremblay, M. Mcniven and T. Landry. 2007. The effect of anti-fouling treatments for the clubbed tunicate on the blue mussel, Mytilus edulis. Aquaculture, 264:205-213.

Lesser, M. P., S. E. Shumway, T. Cuccia and J. Smith. 1992. Impact of fouling organisms on mussel rope culture: interspecific competition for food among suspensionfeeding invertebrates. J. Exp. Mar. Bio. Ecol., 165:91-102.

Lutz-Collins, V., A. Ramsay, P. A. Quijón and J. Davidson. 2009. Invasive tunicates fouling mussel lines: evidence of their impact on native tunicates and other epifaunal invertebrates. Aquatic Invasions, 4:213-220.

Mccann, L. D., K. K. Holzer, I. C. Davidson, G. V. Ashton, M. D. Chapman and G. M. Ruiz. 2013. Promoting invasive species control and eradication in the sea: Options for managing the tunicate invader Didemnum vexillum in Sitka, Alaska. Mar. Pollut. Bull., 77:165-171.

Meenakshi, V. K. and S. Senthamarai. 2013. Diversity of Ascidians from the Gulf of Mannar, in: Ecology and Conservation of Tropical Marine Faunal Communities. pp. 213-229.

Moring, J. R. and K. A. Moring. 1975. Succession of Net Biofouling Material and its Role in the Diet of Pen-Cultured Chinook Salmon. Progress. Fish-Culturist., 37:2730.

Nair, K. V. K. 1999. Marine biofouling and its control with particular reference to condenser-cooling circuits of power plants-An overview. J. Indian Inst. Sci., 79:497-511

Rolheiser, K. C., A. Dunham, S. E. Switzer, C. M. Pearce and T. W. Therriault. 2012. Assessment of chemical treatments for controlling Didemnum vexillum, other biofouling, and predatory sea stars in Pacific oyster aquaculture. Aquaculture, 364-365, 53-60.

Rosa, M., B. A. Holohan, S. E. Shumway, S. G. Bullard, G. H. Wikfors, S. Morton and T. Getchis. 2013. Biofouling ascidians on aquaculture gear as potential vectors of harmful algal introductions. Harmful Algae, 23:1-7.

Switzer, S. E., T. W. Therriault, A. Dunham and C. M. Pearce. 2011. Assessing potential control options for the invasive tunicate Didemnum vexillum in shellfish aquaculture. Aquaculture, 318:145-153.

Taylor, J. J., P. C. Southgate and R. A. Rose. 1997. Fouling animals and their effect on the growth of silver-lip pearl oysters, Pinctada maxima (Jameson) in suspended culture. Aquaculture, 153:31-40.

Velayudhan, T. S. 1987. Studies on the settlement of barnacles at different depths in the pearl oyster farm at Tuticorin, in: National Seminar on Shellfish Resources and Farming. pp. 301-305.

Velayudhan, T. S. 1983. On the occurrence of shell boring polychaetes and sponges on pearl oyster Pinctada fucata and control of boring organisms, in: Proceedings on the Symposium on Coastal Aquaculture. pp. 614-618. 